\section{Physiological potential of green bean seeds treated with Bacillus subtilis}

\author{
Helio Fernandes Ibanhes Neto ${ }^{1 *}$ (D), Ananda Covre da Silva ${ }^{1}$ (D) Ciro Hideki \\ Sumida $^{1}$ (D), Marjori dos Santos Gouveia ${ }^{1}$ (D), Verônica Pellizzaro ${ }^{1}$ (D), Lúcia \\ Sadayo Assari Takahashi ${ }^{1}$
}

\begin{abstract}
The association between beneficial microorganisms and green beans can accelerate establishment in the field. The objective of this study was to investigate the influence of seed treatments in different doses of Bacillus subtilis on the physiological potential of green beans. Seeds from the cultivar Macarrão Baixo were used. The study used a completely randomized design in a double factorial scheme with factor $A$ in the treatments: Pelliculation (PC), Pelliculation with Drying (PCD), Pre-Imbibition (PI), Biopriming (BP); factor $B$, doses of $B$. subtilis: $0 ; 7 ; 14$ and $28 \mathrm{~mL}$ of a commercial product.kg of $\mathrm{seed}^{-1}$, and a control. The following treatments were applied: moisture content analysis, first count and final germination, electrical conductivity, length, fresh and dry seedling weight, speed index, and final emergence. Analysis of variance was applied to the data and when significant, it was compared using Tukey's test and polynomial regression; for the absolute control, orthogonal contrast was applied, with $p<$ 0.05 for all analyses. The treatments did not impair seed viability. Vigor benefited with the use of $\mathrm{PI}$ and doses between 16 and $20 \mathrm{~mL}$ of p.c.kg of seed ${ }^{-1}$. PI alone had the best performance. Biopriming, associated with $B$. subtilis, favors the vigor of green beans.
\end{abstract}

Index terms: Phaseolus vulgaris L., physiological conditioning, microbiolization, rhizobacteria, emergence of plants.

\section{Potencial fisiológico de sementes de feijão-vagem tratadas com Bacillus subtilis}

RESUMO: A associação de microrganismos benéficos com sementes de feijão-vagem, pode acelerar o estabelecimento da cultura a campo. O objetivo do trabalho foi verificar a influência de tipos de tratamentos de sementes com diferentes doses de Bacillus subtilis sobre potencial fisiológico de feijão-vagem. Utilizou-se sementes de feijão-vagem da cultivar Macarrão Baixo. $O$ delineamento inteiramente casualizado em esquema fatorial duplo $(4 \times 4+1)$ teve no fator $A$ os quatro tipos de tratamentos de sementes: Peliculização $(P C)$, Peliculização com Secagem (PCS), Pré-Embebição (PE), Biopriming (BP); e no fator B quatro doses de $B$. subtilis: $0 ; 7 ; 14$ e $28 \mathrm{~mL}$ de produto comercial.kg de semente ${ }^{-1}$, e uma testemunha absoluta sem tratamentos $(4 \times 4+1)$. Realizou-se os seguintes testes: grau de umidade, primeira contagem de germinação, germinação, condutividade elétrica, comprimento de plântulas, massa fresca e seca de plântulas, velocidade de emergência e emergência de plântulas. Os tratamentos não prejudicaram a viabilidade. $O$ vigor foi beneficiado com uso de PE e doses entre 16 e $20 \mathrm{~mL}$ de p.c..kg de semente ${ }^{-1}$, e prejudicado pelo uso da peliculização. $O$ destaque de $\mathrm{PE}$ e $\mathrm{BP}$ se mantém em relação à testemunha absoluta. A PE e BP associados com B. subtilis favorecem características como comprimento, massa e número de raízes secundárias de feijão-vagem.

Termos para indexação: Phaseolus vulgaris L., condicionamento fisiológico, microbiolização, rizobactérias, emergência.
Journal of Seed Science, v.43, e202143016, 2021

http://dx.doi.org/10.1590/ 2317-1545v43248603

\begin{abstract}
*Corresponding author E-mail: helioibanhes@hotmail.com
\end{abstract}

Received: 2/9/2021. Accepted: 5/17/2021.

\footnotetext{
${ }^{1}$ Departamento de Agronomia, Universidade Estadual de Londrina, Caixa Postal 10.011, 86057-970 Londrina, PR, Brasil.
} 


\section{INTRODUCTION}

Green beans are propagated by seeds, which allows for practicality and mechanization in cultivation, but it requires quality of the seed lot for desired final stand to be achieved. Adequate edaphoclimatic conditions are also needed to allow for growth and development in the initial phase, the most critical one of green bean plants, owing to their susceptibility to phytosanitary problems (Brito et al., 2013; Krause et al., 2012; Seif et al., 2016).

Quality characteristics depend directly on the conditions of seed production, processing and storage (Santanna et al., 2019). To protect these intrinsic characteristics of the seeds that determine the productive potential of green beans, pelliculation treatments are often used with chemical and/or biological products. This forms a protective layer over the seeds and roots of seedlings against the entry of phytopathogens (Fantinel et al., 2015).

According to Singh et al. (2016), a biological alternative used for seed treatment is Plant Growth Promoting Rhizobacteria (PGPR). Among the species with proven effect, Bacillus subtilis has had remarkable results, with symbiotic associations through chemical interactions, promoting growth through phytohormones, inducing the defense system and suppressing diseases. The same authors found that the inoculation of rice seeds with the bioflavonoid rutin increased seedling length and the photosynthetic pigments of chlorophyll and carotenoids.

Joshua and Mmbaga (2020) isolated the main pathogenic fungi of the genera Fusarium spp. and Macrophomina phaseolina from green bean roots for in vitro application assays of antagonistic microorganisms. B. subtilis was one of the promising microorganisms for in vivo testing of biological control.

Analyzing application in corn seeds, Junges et al. (2013) reported that $B$. subtilis interferes in the growth and development of plants through the phytohormones auxin, gibberellin, cytokinins and abscisic acid. This process is optimized according to the type of contact provided between priming mixture and seeds, such as in physiological conditioning. This technique consists of controlled soaking of the seeds in a priming mixture with microorganisms, to start the germination process (which allows the degradation of reserves), with interruption before root protrusion. In addition to inoculation of the microorganism, uniform seed lot vigor and rapid emergence are other advantages of the technique.

Tu et al. (2016) found that microcapsules of $B$. subtilis that covered cotton seeds increased the length, and the dry and fresh weight of seedlings by up to $50 \%$, pointing to an alternative treatment to seed coating. Prathibha and Siddalingeshwara (2013) found that $B$. subtilis affected the physiological potential of sorghum seeds and the nutritional content estimated by proteins and carbohydrates. El-Wakil and Essa (2020) found that the treatment of barley seeds using biopriming, as well as the use of soil waterlogging with a priming mixture based on $B$. subtilis, stimulates the length and the dry and fresh weights of seedlings, in addition to the ability to stimulate the systemic resistance of seedlings infected with Xanthomonas campestres pv. translucent.

Therefore, the use of seeds inoculated with $B$. subtilis treated in different ways, can lead to gains in seedling vigor, initial protection against pathogens and reduction in the critical period of the crop in the field (Petropoulos et al., 2020). Thus, the objective of this study was to investigate the influence of types of seed treatments with different doses of $B$. subtilis on the physiological potential of green beans.

\section{MATERIAL AND METHODS}

The experiment was conducted at the Seed Analysis Laboratory of the State University of Londrina. A lot of green bean seeds of the cultivar Macarrão Baixo (Isla Sementes ${ }^{\circledR}$ ) was used. First, water content of the lot was characterized using the oven method at $105 \pm 3{ }^{\circ} \mathrm{C}$ for 24 hours, with two subsamples of 4.5 grams each. The result on a wet basis (w.b.) was expressed as a percentage with two decimal places (Brasil, 2009). After the seed treatments, water content was evaluated again.

The lot imbibition curve was designed to define the germination phases with four replicates of twenty seeds. Seeds with initial water content of $11 \%$, and known weight, were placed between three sheets of germitest paper 
moistened with distilled water at 2.5 times the dry paper weight, and kept in a Mangelsdorf germinator at $20^{\circ} \mathrm{C}$. During the first seven hours, weighings were performed at one-hour intervals, and then at two- to three-hour intervals. The evaluations were ended after detection of the beginning of phase III of germination, characterized by root protrusion by more than $50 \%$ of the sample.

The priming mixtures for the treatments were prepared with doses of Bacillus subtilis, using the commercial product (cp) Serenade [B. subtilis strain QST 713 (minimum 1 x 109 UFC. ${ }^{-1}$ of active ingredient)] Bayer Cropscience ${ }^{\circledR}$. Doses 0 (water only), 7, 14 and $28 \mathrm{~mL}$ of pc.kg-1 of seeds were diluted in $100 \mathrm{~mL}$ of distilled water. The additional (absolute control) did not receive any treatment.

Based on the imbibition curve to define the contact time between priming mixtures and seeds, four forms of seed treatments were proposed: Pelliculation (PC): seeds with storage water content of $11 \%$, were immersed for three minutes in a priming mixture composed of distilled water and doses of $B$. subtilis contained in a plastic bag for use after treatment. Pelliculation with drying (PCD): this treatment was similar to the previous one, but the lot was dried at room temperature for 96 hours for subsequent use. Pre-imbibition (PI): seeds with storage moisture of 11\%, were placed between three sheets of germitest paper, moistened with priming mixtures at 2.5 times the dry paper weight, inside plastic trays. The treatment took place in a Mangelsdorf germinator at $20^{\circ} \mathrm{C}$ and absence of light lasting until the entry into phase III of germination (46 hours). Biopriming (BP): treatment carried out similarly to PI with additional drying after soaking at room temperature for 96 hours.

For the evaluation of treatments: Electrical Conductivity (EC), using four replicates of 25 seeds inside disposable plastic cups, immersed in $75 \mathrm{~mL}$ of deionized water for 24 hours at $25^{\circ} \mathrm{C}$. The results found with a conductivity meter (DIST ${ }^{\circledR} 6 \mathrm{EC} / \mathrm{TDS} /$ Hanna Temperature Meter) were expressed in $\mu \mathrm{S} \cdot \mathrm{cm}^{-1} \cdot \mathrm{g}^{-1}$ of seeds (Vieira and Kryzanowski, 1999).

Germination consisted of four replicates of fifty seeds placed between three sheets of germitest paper, moistened with distilled water at 2.5 times the dry paper weight. The rolls were kept in a Mangelsdorf germinator at $20^{\circ} \mathrm{C}$ for five days for First Germination Count (FGC) of normal seedlings, and nine days for final count of the number of Normal (NS), Abnormal (AS) seedlings, and Non-Germinated Seeds (NGS). The result was expressed as a percentage (Brasil, 2009).

Seedling Length: Root length $(\mathrm{RL})$ and shoot length $(\mathrm{SL})$ were determined with the roll method, as performed for the germination test, with four replicates of twenty seeds for each treatment. The results were harvested at seven days after sowing through the analysis of ten normal seedlings and the use of a ruler graduated in millimeters (Nakagawa, 1999). Number of secondary roots (NR), using the same length test; the number of secondary roots equal to or greater than $1 \mathrm{~mm}$ was counted and expressed as an average number of roots per seedling for NR.

Root Dry Weight (RDW) and Shoot Dry Weight (SDW): after the length test, the root and shoots of the seedlings were separated with a scalpel and weighed on a precision scale with four decimal places. The result was expressed as the average in milligrams. These same treatments were submitted to drying at $80^{\circ} \mathrm{C}$ for 24 hours in an air circulation oven. The samples were weighed according to the previous methodology to determine Root Dry Weight (RDW) and Shoot Dry Weight (SDW) (Nakagawa, 1999).

Seedling Emergence (SE), performed with four replications of fifty seeds per treatment, sown in plastic trays ( $21 \times 33$ $x 5 \mathrm{~cm}$ ) containing sand, irrigated regularly. The trays were kept in a greenhouse at a controlled temperature at $25^{\circ} \mathrm{C}$ for eleven days. The result was expressed in percentage of emerged seedlings (Nakagawa, 1999). During the conduction of the test, the number of emerged seedlings was counted on a daily basis to calculate the Emergence Speed Index (ESI), according to the formula of Maguire (1962): $E S I=(E 1 / N 1)+(E 2 / N 2)+(E n / N n)$, where $E$ is the number of seedlings that emerged on the day of counting, and $\mathrm{N}$ the number of days after sowing.

This study used a completely randomized design in a double factorial scheme $4 \times 4+1$; factor $A$ was types of seed treatments and $B$, doses of $B$. subtilis, and the additional absolute control (AC) without the use of treatments. Data was submitted to analysis of variance (ANOVA) and when significant, qualitative means were analyzed using Tukey's test, and quantitative means were determined using polynomial regression ( $2^{\text {nd }}$ degree). For comparison with the absolute control, the orthogonal contrast test was performed. All tests used 5\% significance. The SISVAR ${ }^{\circledR}$ software (Ferreira, 2014) was used for data analysis. 


\section{RESULTS AND DISCUSSION}

Figure 1 shows the behavior of the soaking curve with distilled water from seeds for the cultivar Macarrão Baixo. The greatest amount of water absorbed was found in phase I, between 0 and 21 hours. In phase II, the gain in moisture was less expressive despite the long duration, about 27 hours. Phase III starts after 46 hours of controlled soaking; then, based on the behavior of the curve, the treatments were applied to the lots.

Therefore, to use the technique correctly and with maximum efficiency in this lot of green beans, soaking should be interrupted at around 46 hours, when water content is approximately $55 \%$. Effective physiological conditioning of seeds is based on knowledge of the stages of seed soaking, thus avoiding not rapid soaking, which causes moisture damage but also slow soaking and underutilization of reserves; or allowing root protrusion, which causes loss of drying capacity. Thus, the process can be optimized both for seed lot processing and for the operational part of applying the technique by finishing it before phase III (Taylor et al., 1992).

The initial water content of the lot was $11.32 \%$. The post-treatment contents were 20.08 and $24.80 \%$ for pelliculation (PC) and pelliculation with drying (PCD), respectively. This indicates a gain in water content ranging from 9 to $13 \%$ during pelliculation, which abruptly immerses the seeds in water or priming mixture. Furthermore, water content in the pelliculation treatments indicates that the metabolism of the seeds did not evolve close to the point of protrusion. Preimbibition (PI) was 34.24\% and Biopriming (BP) was 35.61\%, i.e., gains of 23 and 24 percentage points in comparison to the initial moisture content of the lot. The PCD and biopriming (BP) treatments were subjected to drying after the treatment, regaining a moisture content of $11 \%$ (Table 1 ).

In Table 2, the analysis of variance indicates that the double interaction was significant for the characteristics shoot length (SL), number of secondary roots (NR), root fresh weight (RFW), shoot fresh weight (SFW), root dry weight (RDW) and shoot dry weight (SDW). In the analysis of isolated factors, for doses, only the emergence speed index (ESI)

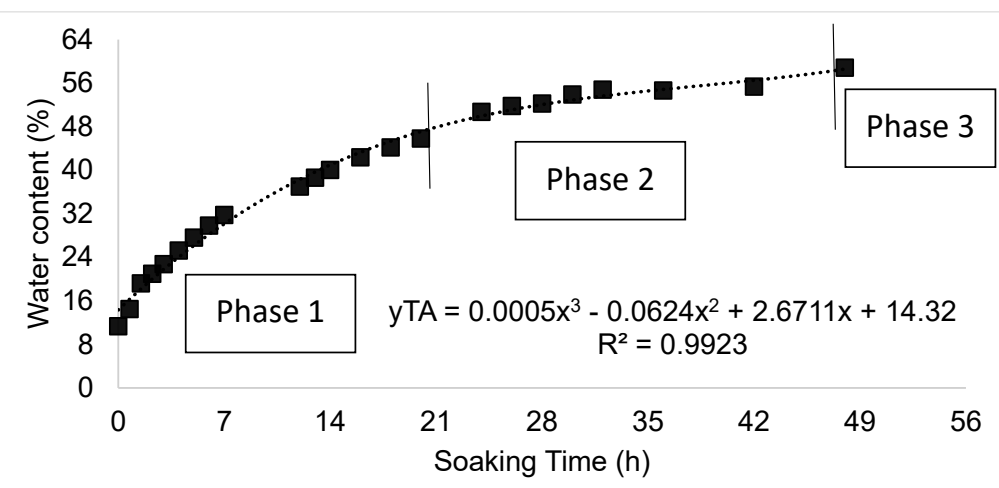

Figure 1. Soaking curve to characterize the germination phases of the green bean seed lot, cultivar Macarrão Baixo.

Table 1. Water content after treatments applied to green bean seeds.

\begin{tabular}{cccc}
\hline & Initial & After treatment & After drying \\
\cline { 2 - 4 } & & $(\%)$ & - \\
\hline PC $^{1}$ & & 20.08 & 11.52 \\
PCD & 11.32 & 24.80 & - \\
PI & & 34.24 & 11.77 \\
BP & & 35.61 & \\
\hline
\end{tabular}

${ }^{1}$ PC: Pelliculation; PCD: Pelliculation with Drying; PI: Pre-imbibition and BP: Biopriming. 
was significant, while for the treatments, the characteristics electrical conductivity (EC), first germination count (FGC), root length (RL), ESI and final emergence (FE) showed statistical difference. Viability of normal seedlings (NS) was not affected by the treatments and doses applied.

The treatments pre-imbibition (PI) and biopriming (BP) provided the seeds with slow and gradual water absorption. However, the opposite occurred in the pelliculation (PC) treatment, owing to complete immersion in the priming mixture, causing an abrupt entry of water. This type of soaking causes initial damage, especially in deteriorated lots, first affecting vigor and then viability.

Germination and vigor are characteristics associated with the physiological condition of seeds, also called quality. The decrease in vigor in each treatment that was tested on green beans, as indicated by the tests applied, may be associated with imbibition processes that caused structural damage, such as membrane lysis and cell content leakage. During the decrease in vigor, techniques such as physiological conditioning can be used to reduce damage, in addition to leveling the vigor of different lots, providing speed and uniformity in germination and emergence, and tolerance to development in unfavorable environments (Lima and Marcos-Filho, 2010).

Another factor that can affect treatments is the fact that hydration did not occur evenly in all seed parts, which may have contributed to greater damage in the treatments with pelliculation. In legumes such as green beans, the main water entry points are the region opposite the hilum, followed by the micropyle and hilum region ( $20 \%$ water in the initial 24 hours of soaking). Absorption in these regions depends on the amount of water available and the form of contact with the seed. Immersion leads to a large difference in water potential, owing to the degree of storage moisture, which, together with integument integrity, causes moisture damage (Marcos-Filho, 2015).

Table 2. Analysis of variance of the interaction between seed treatments based on pelliculation, pre-imbibition and biopriming associated with doses of $B$. subtilis in green beans.

\begin{tabular}{|c|c|c|c|c|c|c|c|}
\hline & Source of variation & Seed treatment & Dose & Treatment x Dose & Residue & CV (\%) & Overall mean \\
\hline $\mathrm{DF}$ & & 3 & 3 & 9 & 48 & & \\
\hline \multirow{14}{*}{ MS } & NS & 120.42 & 48.25 & 31.31 & 51.08 & 11.92 & 59.94 \\
\hline & AS & 46.75 & 53.75 & 45.78 & 54.46 & 22.93 & 32.19 \\
\hline & NGS & 36.17 & 46.17 & 24.17 & 24.88 & 63.33 & 7.88 \\
\hline & EC & $24750.36^{*}$ & 173.67 & 154.09 & 136.61 & 8.98 & 130.11 \\
\hline & FGC & $231.68 *$ & 75.43 & 65.15 & 51.79 & 12.36 & 58.23 \\
\hline & RL & $2422.86^{*}$ & 204.02 & 240.66 & 126.64 & 14.23 & 79.10 \\
\hline & SL & $1904.12 *$ & 65.22 & $303.26^{*}$ & 62.46 & 13.87 & 57.00 \\
\hline & NR & $211.38^{*}$ & $13.08 *$ & $22.21 *$ & 3.74 & 15.66 & 12.34 \\
\hline & RFW & $2710.45^{*}$ & 162.61 & $319.12 *$ & 126.29 & 14.11 & 79.64 \\
\hline & SFW & 199015.99* & 14777.39 & $21234.04 *$ & 6615.77 & 15.38 & 528.87 \\
\hline & RDW & $5.46 *$ & 0.88 & $0.99 *$ & 0.34 & 10.32 & 5.79 \\
\hline & SDW & $474.38 *$ & $127.02 *$ & $746.94^{*}$ & 737.84 & 15.48 & 25.33 \\
\hline & ESI & $155.62 *$ & 133.59 & 53.95 & 31.50 & 13.39 & 41.90 \\
\hline & $\mathrm{FE}$ & $382.06 *$ & 48.40 & 49.73 & 60.81 & 9.93 & 78.53 \\
\hline
\end{tabular}

*Significant at 5\% by Tukey's test. DF: Degrees of freedom; MS: Mean square; NS: Normal seedlings; AS: Abnormal seedlings; NGS: Non-germinated seeds; EC: Electrical conductivity; FGC: First germination count; RL: Root length; SL: Shoot length; NR: Number of roots; RFW: Root fresh weight; SFW: Shoot fresh weight; RDW: Root dry weight; SDW: Shoot dry weight; ESI: Emergence speed index; FE: Final emergence. 
Aragão et al. (2002) found similar favorable responses to the use of physiological conditioning when they submitted bean seeds to one, two and three hydration cycles in a humid chamber for six, twelve and twenty-four hours, followed by drying to storage. The authors found that germination was not affected, but vigor was favored, owing to the better reorganization of membranes and cell repair systems in a controlled condition, avoiding the leaching of sugars and ions.

Further analysis of the treatments within the doses indicated greater shoot length (SL) when PI was applied, with gains above $30 \%$, compared to the second best mean in the doses of 0.0 and $7.0 \mathrm{~mL}$. PCD was the worst treatment for both doses, in addition to the $14 \mathrm{~mL}$ dose, with a difference above $48 \%$. On the other hand, when $28.0 \mathrm{~mL}$ was applied, PCD showed gains of up to $77 \%$ in comparison to the other treatments (Table 3 ).

Number of roots (NR) was higher for the PC treatment at a dose of $0.0 \mathrm{~mL}$ in up to four roots. However, PI was found to be the best treatment with a difference of 10.6 roots at dose 7,0; 6.5 roots at 14.0 and 5.6 roots at 28.0 in comparison to the second highest mean. For root fresh weight (RFW), there was significance within the doses 7.0, 14.0, $28.0 \mathrm{~mL}$. Shoot fresh weight (SFW) presented a prominence of up to $143 \%$ when using a dose of $7.0 \mathrm{~mL}$ in PI, occurring similarly within the $14.0 \mathrm{~mL}$ dose, with a difference of up to $67 \%$. In the $28.0 \mathrm{~mL}$ dose, there was a superiority between 50 and $84 \%$ in comparison to PC (Table 3).

For root dry weight (RDW), the doses of $7.0 \mathrm{~mL}$ for PI and BP were 23 and $50 \%$ higher than for PCD and PC, respectively. At the $28.0 \mathrm{~mL}$ dose, PC had a lower performance than the other seed treatments (30 to $48 \%$ ). When analyzing shoot dry weight (SDW), the PCD and PI treatments were found to be significantly higher by $30 \%$ at the $0.0 \mathrm{~mL}$ dose in comparison to BP. At the $7.0 \mathrm{~mL}$ dose, $\mathrm{PI}$ had a higher mass difference of up to $119 \%$. For the dose of $14.0, \mathrm{PI}$ and BP stood out positively; gains were $38 \%$ higher than those of PC and PCD. And at the dose of $28.0 \mathrm{~mL}$, all treatments had better results than PC, with nearly twice as much weight gain (Table 3).

Table 4 shows the results for doses within lots; shoot length (SL) was significant when applied to the PC and PI treatments. The former was harmful with increasing doses, indicated by the maximum effect at dose zero with $49.5 \mathrm{~mm}$, while the latter showed increasing response, using $16.7 \mathrm{~mL}$ for $50 \%$ gain in size. For number of roots (NR), there was the

Table 3. Further analysis of the means of seed treatments based on pelliculation, pre-imbibition and biopriming within the doses of $B$. subtilis for the vigor characteristics of green bean seeds.

\begin{tabular}{|c|c|c|c|c|c|c|c|c|c|c|c|}
\hline \multicolumn{12}{|c|}{ Doses (mL cp.kg seed $\left.{ }^{-1}\right)$} \\
\hline & & 0 & 7 & 14 & 28 & & & 0 & 7 & 14 & 28 \\
\hline \multirow{4}{*}{$\vec{n}$} & $\mathrm{PC}^{1}$ & $53.5 \mathrm{bc} *$ & $62.3 a b$ & $55.2 \mathrm{a}$ & $47.0 \mathrm{~b}$ & \multirow{4}{*}{$\underset{⿱ 亠 䒑}{\mathbf{n}}$} & PC & 469.9 a & $305.9 c$ & $429.4 \mathrm{c}$ & $353.8 \mathrm{~b}$ \\
\hline & PCD & $39.0 \mathrm{c}$ & $45.7 \mathrm{c}$ & $37.1 \mathrm{~b}$ & $83.5 \mathrm{a}$ & & PCD & $555.8 \mathrm{a}$ & $504.5 \mathrm{~b}$ & $535.6 \mathrm{bc}$ & $530.2 \mathrm{a}$ \\
\hline & $\mathrm{PI}$ & $71.6 \mathrm{a}$ & $71.6 \mathrm{a}$ & $56.3 \mathrm{a}$ & $58.2 \mathrm{~b}$ & & $\mathrm{PI}$ & $531.1 \mathrm{a}$ & $744.6 \mathrm{a}$ & $719.8 \mathrm{a}$ & $650.4 \mathrm{a}$ \\
\hline & $\mathrm{BP}$ & $54.7 \mathrm{~b}$ & $54.5 \mathrm{bc}$ & $60.1 \mathrm{a}$ & $61.3 \mathrm{~b}$ & & $\mathrm{BP}$ & $440.3 \mathrm{a}$ & $523.7 \mathrm{~b}$ & $597.2 \mathrm{ab}$ & $574.9 \mathrm{a}$ \\
\hline \multirow{4}{*}{$\stackrel{\Upsilon}{z}$} & PC & $13.2 \mathrm{a}$ & $10.4 \mathrm{~b}$ & $11.9 \mathrm{~b}$ & $9.3 \mathrm{~b}$ & \multirow{4}{*}{ 方 } & PC & $5.5 \mathrm{a}$ & $4.4 \mathrm{~b}$ & $5.6 \mathrm{a}$ & $4.3 \mathrm{~b}$ \\
\hline & PCD & $9.5 \mathrm{~b}$ & $8.5 \mathrm{~b}$ & $11.0 \mathrm{~b}$ & $9.6 \mathrm{~b}$ & & PCD & $5.5 \mathrm{a}$ & $5.4 b$ & $5.9 \mathrm{a}$ & $5.6 \mathrm{a}$ \\
\hline & $\mathrm{PI}$ & $12.8 \mathrm{ab}$ & $22.1 \mathrm{a}$ & $18.4 \mathrm{a}$ & $17.5 \mathrm{a}$ & & $\mathrm{PI}$ & $5.6 \mathrm{a}$ & $6.6 \mathrm{a}$ & $6.2 \mathrm{a}$ & $6.1 \mathrm{a}$ \\
\hline & $\mathrm{BP}$ & $9.2 \mathrm{~b}$ & $11.5 \mathrm{~b}$ & $10.7 \mathrm{~b}$ & $11.9 \mathrm{~b}$ & & $\mathrm{BP}$ & $5.4 \mathrm{a}$ & $6.6 \mathrm{a}$ & $6.6 \mathrm{a}$ & $6.4 \mathrm{a}$ \\
\hline \multirow{4}{*}{ 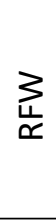 } & $P C$ & $73.8 \mathrm{a}$ & $51.5 b$ & $65.9 \mathrm{~b}$ & $50.9 \mathrm{~b}$ & \multirow{4}{*}{ 方 } & PC & $22.3 a b$ & $15.4 \mathrm{c}$ & $21.8 \mathrm{~b}$ & $16.5 \mathrm{~b}$ \\
\hline & PCD & $82.6 \mathrm{a}$ & $79.0 \mathrm{a}$ & $86.4 a b$ & $81.6 \mathrm{a}$ & & PCD & $25.5 \mathrm{a}$ & $20.3 \mathrm{bc}$ & $22.8 \mathrm{~b}$ & $28.4 \mathrm{a}$ \\
\hline & $\mathrm{PI}$ & $72.7 \mathrm{a}$ & $90.4 \mathrm{a}$ & $91.1 \mathrm{a}$ & $90.2 \mathrm{a}$ & & PI & $25.2 \mathrm{a}$ & $33.7 \mathrm{a}$ & $36.0 \mathrm{a}$ & $33.9 \mathrm{a}$ \\
\hline & $\mathrm{BP}$ & $78.0 \mathrm{a}$ & $93.5 \mathrm{a}$ & $93.4 \mathrm{a}$ & $93.2 \mathrm{a}$ & & $\mathrm{BP}$ & $17.2 \mathrm{~b}$ & $23.8 \mathrm{~b}$ & $31.5 \mathrm{a}$ & $31.3 \mathrm{a}$ \\
\hline
\end{tabular}

*Means followed by different letters in the column are significant at $5 \%$ probability by Tukey's test.

${ }^{1}$ PC: Pelliculation; PCD: pelliculation with drying; PI: Pre-imbibition and BP: Biopriming.

SL: Shoot length $(\mathrm{mm})$; NR: Number of roots; RFW: Root fresh weight (mg.seedling ${ }^{-1}$ ); SFW: Shoot fresh weight (mg.seedling ${ }^{-1}$ ); RDW: Root dry weight (mg.seedling $\left.{ }^{-1}\right)$; SDW: Shoot dry weight $\left(\mathrm{mg}^{\text {. seedling }}{ }^{-1}\right)$. 
same response of significant treatments, and the behavior was similar to that of length. The treatment with PC decreases with increasing dose, with a higher NR (12.6) at the $0.0 \mathrm{~mL}$ dose. With the PI treatment, there was maximum performance at the 16.0 dose $\mathrm{mL}$ with 21 roots.

Root fresh weight (RFW) was also significant when PI was used, with increasing response reaching $19.8 \mathrm{mg}$. seedling ${ }^{-1}$ under the $28.0 \mathrm{~mL}$ dose. The analysis of shoot fresh weight (SFW) showed a statistical difference in the use of doses in the PI and BP treatments, with 16.1 and $19.7 \mathrm{~mL}$, respectively. After quadratic adjustment, they both had an increase by $38 \%$ in comparison to the control (Table 4).

The characterization of root dry weight (RDW) showed significance only for doses in the BP treatment; the most positively responsive difference was found in the $17.9 \mathrm{~mL}$ dose, which resulted in a gain of $1.3 \mathrm{mg}$. seedling ${ }^{-1}$. Shoot dry weight (SDW) showed significance in the PCD treatments with greater response at the $28 \mathrm{~mL}^{\text {dose, with } 28.4 \mathrm{mg} \text {. seedling }}{ }^{-1}$, a gain of $14 \%$

Table 4. Further analysis of the mean doses of $B$. subtilis within the interaction with seed treatments based on pelliculation, pre-imbibition and biopriming for vigor characteristics.

\begin{tabular}{|c|c|c|c|c|c|}
\hline & & Variables & $\mathrm{R}^{2}$ & $\begin{array}{l}\text { Maximum dose } \\
\left.\left(\mathrm{mL}^{2} \mathrm{~kg} \mathrm{seed}\right)^{-1}\right)\end{array}$ & Maximum Effect \\
\hline \multirow{4}{*}{$\vec{n}$} & $P C$ & $\hat{Y}=-0.46 x+49.51 *$ & 54.38 & 0.0 & 49.5 \\
\hline & PCD & $\hat{Y}=57.9$ & - & - & 57.9 \\
\hline & PI & $\hat{Y}=-0.08 x 2+2.51 x+59.14^{*}$ & 53.33 & 16.7 & 80.0 \\
\hline & $\mathrm{BP}$ & $\hat{Y}=55.71$ & - & - & 55.7 \\
\hline \multirow{4}{*}{ 受 } & $P C$ & $\hat{Y}=-0.11 x+12.58 *$ & 63.24 & 0.0 & 12.6 \\
\hline & PCD & $\hat{Y}=9.7$ & - & - & 9.7 \\
\hline & PI & $\hat{Y}=-0.03 \times 2+0.87 x+14.03^{*}$ & 53.33 & 16.0 & 21.0 \\
\hline & $\mathrm{BP}$ & $\hat{Y}=10.8$ & - & - & 10.8 \\
\hline \multirow{4}{*}{$\underset{\sim}{\not{x}}$} & $P C$ & $\hat{Y}=60.5$ & - & - & 60.5 \\
\hline & PCD & $\hat{Y}=82.4$ & - & - & 82.4 \\
\hline & $\mathrm{PI}$ & $\hat{Y}=0.61 x+79.35^{*}$ & 59.34 & 28.0 & 93.2 \\
\hline & $\mathrm{BP}$ & $\hat{Y}=88.8$ & - & - & 88.8 \\
\hline \multirow{4}{*}{$\underset{⿱ 亠 䒑}{\mathbf{w}}$} & $\mathrm{PC}$ & $\hat{Y}=388.5$ & - & - & 388.5 \\
\hline & PCD & $\hat{Y}=531.5$ & - & - & 531.5 \\
\hline & PI & $\hat{Y}=-0.82 x 2+26.30 x+550.08^{*}$ & 83.98 & 16.1 & 760.8 \\
\hline & $\mathrm{BP}$ & $\hat{Y}=-0.42 x 2+16.89 x+436.45^{*}$ & 98.79 & 19.7 & 602.7 \\
\hline \multirow{4}{*}{ 方 } & $\mathrm{PC}$ & $\hat{Y}=5.0$ & - & - & 5.0 \\
\hline & PCD & $\hat{Y}=5.7$ & - & - & 5.7 \\
\hline & $\mathrm{PI}$ & $\hat{Y}=6.2$ & - & - & 6.2 \\
\hline & $\mathrm{BP}$ & $\hat{Y}=-0.01 \times 2+0.14 x+5.56^{*}$ & 89.87 & 17.9 & 6.9 \\
\hline \multirow{4}{*}{ 方 } & $\mathrm{PC}$ & $\hat{Y}=18.0$ & - & - & 18.0 \\
\hline & PCD & $\hat{Y}=0.03 \times 2+0.60 x+24.86^{*}$ & 87.32 & 28.0 & 28.4 \\
\hline & $\mathrm{PI}$ & $\hat{Y}=-0.04 x 2+1.30 x+25.53^{*}$ & 98.24 & 18.1 & 37.2 \\
\hline & $\mathrm{BP}$ & $\hat{Y}=-0.033 \times 2+1.44 x+16.67^{*}$ & 97.68 & 22.1 & 32.6 \\
\hline
\end{tabular}

*Significant at $5 \%$ by Tukey's test.

PC: Pelliculation; PCD: Pelliculation with drying; PI: Pre-imbibition and BP: Biopriming.

SL: Shoot length (mm); NR: Number of roots; RFW: Root fresh weight (mg.seedling ${ }^{-1}$ ); SFW: Shoot fresh weight (mg.seedling ${ }^{-1}$ ); RDW: Root dry weight (mg.seedling $\left.{ }^{-1}\right)$; SDW: Shoot dry weight $\left(\right.$ mg.seedling $\left.^{-1}\right)$. 
over the $0.0 \mathrm{~mL}$ dose. In addition, there were also gains in the PI and BP treatments; the former had an increase by approximately $45 \%$ and the latter, by $95 \%$, in comparison to the control (Table 4 ).

The improved performance of the doses occurred between zero and $16.0 \mathrm{~mL}$ of $\mathrm{cp} . \mathrm{kg}^{-1}$ of seed for the PI treatment, and $18.0 \mathrm{~mL}$ for BP. Finding the ideal dose response for applications of $B$. subtilis favored seedling growth, as found by Junges et al. (2013) for the application of the microorganism by the micropriming technique in corn seeds, with an effect caused by the production of phytohormones by rhizobacteria.

Oliveira et al. (2016) found similar results: bean seeds that was submitted to pelliculation with doses of $B$. subtilis with high vigor had gains in root and shoot dry weight at all doses tested. The authors explained that seeds with high physiological potential can make better use of the conversion of cotyledonary reserves into energy, optimizing phytometric characteristics, as seen in the increasing response of doses within treatments.

Another study that corroborates the results found in this experiment is the one of Cerqueira et al. (2015), who also found gains in root and shoot fresh weight, shoot dry weight and final number of seeds of Phaseolus vulgaris $\mathrm{L}$. with the use of strains of $B$. subtilis. The effect was attributed to the high potential of rhizobacteria strains of the genus Bacillus by colonizing bean seedlings and synthesizing indole-acetic acid. This hormone acts as a signal within cells for cell expansion, division and differentiation, stimulating root growth and increasing the number of root hairs.

The analyses of the dose factor alone were not significant for the characteristics evaluated, while seed treatments were shown in Table 5. The treatments did not affect seed viability. For characteristics that estimate seed vigor, discrepancies were found in the parameters EC, FGC, RL, ESI and FE.

In these tests, the PI treatment stood out positively, while PC remained with lower results compared to the other treatments. The BP and PCD treatments presented intermediate data, therefore, within the doses tested, the seed treatments maintained the same behavior. Rehydration in $\mathrm{BP}$ reduces vigor in comparison to $\mathrm{Pl}$, as found in

Table 5. Isolated analysis of seed treatments based on pelliculation, pre-imbibition and biopriming for green bean viability and vigor characteristics.

\begin{tabular}{ccccc}
\hline Treatment & PC & PCD & PI & BP \\
\hline NS & 58.25 & 57.38 & 63.50 & 60.63 \\
AS & 32.00 & 34.50 & 30.38 & 31.38 \\
NGS & 9.75 & 8.13 & 6.13 & 7.50 \\
EC & $137.52 \mathrm{~b}$ & $174.27 \mathrm{a}$ & $78.77 \mathrm{c}$ & $129.88 \mathrm{~b}$ \\
FGC & $58.00 \mathrm{ab}$ & $53.38 \mathrm{~b}$ & $62.63 \mathrm{a}$ & $58.94 \mathrm{ab}$ \\
RL & $68.68 \mathrm{~b}$ & $72.23 \mathrm{~b}$ & $96.38 \mathrm{a}$ & $79.12 \mathrm{~b}$ \\
SL & $43.88 \mathrm{c}$ & $57.91 \mathrm{~b}$ & $70.50 \mathrm{a}$ & $55.71 \mathrm{~b}$ \\
NR & $11.19 \mathrm{~b}$ & $9.66 \mathrm{~b}$ & $17.71 \mathrm{a}$ & $10.81 \mathrm{~b}$ \\
RFW & $60.53 \mathrm{~b}$ & $82.40 \mathrm{a}$ & $86.86 \mathrm{a}$ & $88.76 \mathrm{a}$ \\
SFW & $388.51 \mathrm{c}$ & $531.5 \mathrm{~b}$ & $661.46 \mathrm{a}$ & $534.02 \mathrm{~b}$ \\
RDW & $5.01 \mathrm{c}$ & $5.67 \mathrm{~b}$ & $6.19 \mathrm{ab}$ & $6.28 \mathrm{a}$ \\
SDW & $18.98 \mathrm{c}$ & $24.22 \mathrm{~b}$ & $32.19 \mathrm{a}$ & $25.93 \mathrm{~b}$ \\
ESI & $37.58 \mathrm{~b}$ & $44.67 \mathrm{a}$ & $41.77 \mathrm{ab}$ & $43.60 \mathrm{a}$ \\
FE & $73.25 \mathrm{~b}$ & $82.63 \mathrm{a}$ & $75.50 \mathrm{ab}$ & $82.75 \mathrm{a}$ \\
\hline
\end{tabular}

${ }^{1}$ Means followed by different letters in the column are significant at $5 \%$ probability.

PC: Pelliculation; PCD: Pelliculation with drying; PI: Pre-imbibition and BP: Biopriming.

NS: Normal seedlings (\%); AS: Abnormal seedlings (\%); NGS: Non-germinated seeds (\%); EC: Electrical Conductivity $\left(\mu S . \mathrm{cm}^{-1} \cdot \mathrm{g}^{-1}\right)$; FGC: First germination count (\%); RL: Root length (mm); SL: Shoot length (mm); NR: Number of roots; RFW: Root fresh weight (mg.seedling $\left.{ }^{-1}\right)$; SFW: Shoot fresh weight (mg.seedling ${ }^{-1}$ ); RDW: Root dry weight (mg.seedling $\left.{ }^{-1}\right)$; SDW: Shoot dry weight (mg.seedling ${ }^{-1}$ ); ESI: Emergence speed index; FE: Final emergence (\%). 
the phytometric characteristics. The best performance of treatments with controlled soaking in vigor assays may be associated with metabolic efficiency.

The reactivation of the embryonic metabolic process is linked to the gradual absorption of water, which depends on factors such as seed coat permeability, seed chemical composition, seed and substrate water content. Seeds that absorb water quickly owing to structural damage or excess water in the environment, as in the treatments that used pelliculation, can harm the repair system; they cannot efficiently reorganize membranes with transition from the gel phase to the crystalline liquid of phospholipids. This leads to an increase in the number of solutes leached to the external environment and a loss in the efficiency of the degradation of reserves (Batista et al., 2015; Silva and Villela, 2011).

In Table 5, electrical conductivity (EC) of the treatments differed by more than $120 \%$ between the use of the PCD (174.27 $\mu \mathrm{S} . \mathrm{cm}^{-1} \cdot \mathrm{g}^{-1}$ of seeds) and PI (78.77 $\mu \mathrm{S} . \mathrm{cm}^{-1} \cdot \mathrm{g}^{-1}$ of seeds) treatments, highlighting the controlled soaking of the seeds. In the First Germination Count (FGC), PI had a better outcome than PCD, with a difference of $9 \%$ of normal seedlings. Root length (RL), once again, indicated the PI treatment was the best treatment, with $21 \%$ more gains over the second-best result $(B P=79.12 \mathrm{~mm})$. Both in ESI and in FE, $P C$ had worse outcomes in comparison to the PCD and BP treatments. The use of pelliculation was $16 \%$ and $12 \%$ worse than in ESI and final emergence, respectively.

The number of leachates in the electrical conductivity test was significantly higher in the PCD treatment at all doses tested and in comparison to the Absolute Control (AC), while the seeds of the PI treatment showed an average decrease of $50 \mu \mathrm{S} . \mathrm{cm}^{-1} \cdot \mathrm{g}^{-1}$ of seeds. For root length (RL), the PCD treatment with a dose of $28.0 \mathrm{~mL}, \mathrm{PI} 0.0$ and $7.0 \mathrm{~mL}$, in addition to BP 14.0 and $28.0 \mathrm{~mL}$, also had significant gains over AC. For shoot length (SL), only PCD and the $14.0 \mathrm{~mL}$ dose had a lower yield than the control, while PC $7.0 \mathrm{~mL}$, PCD $28.0 \mathrm{~mL}$ and PI at the doses 0.0 and $7.0 \mathrm{~mL}$ had greater length than AC (Table 6).

The results of the analysis of Number of Roots (NR) were better than those of the control when the seeds were treated with PC at a dose of $0.0 \mathrm{~mL}$ and with PI at doses of 7.0, 14.0 and $28.0 \mathrm{~mL}$. When analyzing Root Fresh Weight (RFW), significantly higher responses than those of AC were found for seeds treated with PCD and BP, and at doses 7.0, 14.0 and $28.0 \mathrm{~mL}$ in PI. For Shoot Fresh Weight (SFW), only the use of PC $7.0 \mathrm{~mL}$ had a performance below expectations without application, and PI 7.0, 14.0 and $28.0 \mathrm{~mL}$, in addition to BP at doses of 14,0 and $28.0 \mathrm{~mL}$, had better results than those of the control treatment (AC).

The analysis of Root Dry Weight (RDW) indicated significance for values above those of AC, such as PCD at a dose of 14.0, PI and BP at doses of 7.0, 14.0 and $21.0 \mathrm{~mL}$. For Shoot Dry Weight (SDW), PC 7.0 and $28.0 \mathrm{~mL}$, in addition to $B P, 0.0$ responses were lower than that of $A C$ weight, while PI 7.0, 14.0 and 28.0, and BP 14.0 and $28.0 \mathrm{~mL}$ had increased weight.

In the comparison between AC and the other treatments, for ESI of the treatments and PCD doses 7.0 and 28.0 $\mathrm{mL}$ and in the BP $28.0 \mathrm{~mL}$, the ESI presented higher values compared to the non-application of treatment and product. Finally, in Final Emergence (FE) only PCD 7.0 was significant in comparison to the absolute control.

The gains from the PI and BP treatments were maintained in comparison to the absolute control (AC) for most of the growth and development traits analyzed. There was the lower leaching of exudates in the electrical conductivity of PI and higher of PCS. The characteristics of length, number of roots, and fresh and dry weight of the seedlings also showed gains for the treatments with controlled soaking, especially at the doses 7.0 and 14.0 $\mathrm{mL}$ of $\mathrm{cp} . \mathrm{kg}^{-1}$ of seed in $\mathrm{PI}$ and $14.0 \mathrm{~mL}$ in BP. This result indicates that techniques are advantageous compared to the use of untreated seeds. 
Table 6. Comparative analysis by orthogonal contrast between absolute control in comparison to types of seed treatments based on pelliculation, pre-imbibition and biopriming and doses of $B$. subtilis used in green bean seeds for vigor characteristics.

\begin{tabular}{|c|c|c|c|c|c|c|c|c|c|c|c|}
\hline & $\mathrm{EC}$ & $\mathrm{FGC}$ & $\mathrm{RL}$ & SL & NR & RFW & SFW & RDW & SDW & ESI & $\mathrm{FE}$ \\
\hline $\begin{array}{l}\text { Treat./ } \\
\text { Dose }\end{array}$ & & & & & & Means & & & & & \\
\hline \multirow[t]{2}{*}{$A C$} & 129.92 & 61.5 & 64.88 & 49.45 & 10.4 & 57.7 & 446.45 & 4.97 & 23.17 & 39.73 & 75 \\
\hline & \multicolumn{11}{|c|}{ Estimates } \\
\hline $\mathrm{PC} / 0.0$ & -3.15 & -7 & 10.6 & 4.1 & $2.78^{*}$ & 16.11 & 18.45 & 0.62 & -0.9 & 0.16 & 2.5 \\
\hline PC/7.0 & 2.01 & 1 & 5.1 & $12.9 *$ & -0.03 & -6.21 & $-140.54^{*}$ & -0.5 & $-7.77^{*}$ & -0.19 & 0.5 \\
\hline PC/14.0 & 9.64 & -7 & 16.8 & 5.8 & 1.53 & 8.2 & -17.06 & 0.64 & -1.43 & -4.39 & -9 \\
\hline $\mathrm{PC} / 28.0$ & $21.89^{*}$ & -1 & 6.6 & -2.5 & -1.1 & -6.79 & -92.62 & -0.58 & $-6.66^{*}$ & -4.17 & -1 \\
\hline PCD/0.0 & $41.84 *$ & -3 & -7.1 & -10.4 & -0.88 & $24.87^{*}$ & 109.32 & 0.59 & 2.3 & 0.02 & 6 \\
\hline PCD/7.0 & $48.59 *$ & -13 & 9.7 & -3.7 & -1.9 & $21.34^{*}$ & 58.02 & 0.5 & -2.89 & $10.05^{*}$ & $11.50 *$ \\
\hline PCD/14.0 & $44.97^{*}$ & -7 & 2 & $-12.4^{*}$ & 0.6 & $28.66^{*}$ & 89.11 & $1.00 *$ & -0.39 & 1.08 & 4.5 \\
\hline PCD/28.0 & $41.97 *$ & -10 & $43.3^{*}$ & $34.1^{*}$ & -0.78 & $23.93^{*}$ & 83.76 & 0.71 & 5.18 & $8.60^{*}$ & 8.5 \\
\hline $\mathrm{Pl} / 0.0$ & $-47.42 *$ & 2 & $35.0 *$ & $22.1 *$ & 2.4 & 15.02 & 84.67 & 0.71 & 2.05 & -0.16 & -2 \\
\hline $\mathrm{PI} / 7.0$ & $-57.25^{*}$ & 3 & $31.3^{*}$ & $22.2^{*}$ & $11.68^{*}$ & $32.67^{*}$ & $298.15^{*}$ & $1.71 *$ & $10.50^{*}$ & 2.87 & -1 \\
\hline $\mathrm{Pl} / 14.0$ & $-52.89 *$ & -1 & 8 & 6.9 & $8.03 *$ & $33.41^{*}$ & $273.33^{*}$ & $1.29 *$ & $12.85^{*}$ & 2.3 & 4 \\
\hline $\mathrm{Pl} / 28.0$ & $-47.06 *$ & 1 & 9.2 & 8.8 & $7.13^{*}$ & $35.53^{*}$ & $203.90 *$ & $1.21 *$ & $10.69 *$ & 3.15 & 1 \\
\hline $\mathrm{BP} / 0.0$ & -0.65 & 2 & 7.2 & 5.3 & -1.2 & $20.28^{*}$ & -6.21 & 0.51 & $-5.99 *$ & -3.1 & 4.5 \\
\hline $\mathrm{BP} / 7.0$ & -3.35 & -3 & 11.9 & 5.1 & 1.05 & $35.77^{*}$ & 77.26 & $1.63 *$ & 0.62 & 3.81 & 10.5 \\
\hline $\mathrm{BP} / 14.0$ & 2.91 & -11 & $20.7^{*}$ & 10.6 & 0.3 & $35.70 *$ & $150.74 *$ & $1.64 *$ & $8.32 *$ & 3.53 & 6.5 \\
\hline $\mathrm{BP} / 28.0$ & 0.94 & 2 & $17.8^{*}$ & 11.8 & 1.5 & $32.49 *$ & $128.48 *$ & $1.48^{*}$ & $8.08 *$ & $11.23^{*}$ & 9.5 \\
\hline
\end{tabular}

*Significant at $5 \%$.

AC: Absolute control; PC: Pelliculation; PCD: Pelliculation with drying; PI: Pre-imbibition and BP: Biopriming.

NS: Normal seedlings (\%); AS: Abnormal seedlings (\%); NGS: Non-germinated seeds (\%); EC: Electrical Conductivity $\left(\mu S . \mathrm{cm}^{-1} \cdot \mathrm{g}^{-1}\right)$; FGC: First germination count (\%); RL: Root length $(\mathrm{mm})$; SL: Shoot length $(\mathrm{mm})$; NR: Number of roots; RFW: Root fresh weight (mg.seedling ${ }^{-1}$; SFW: Shoot fresh weight (mg.seedling $\left.{ }^{-1}\right)$; RDW: Root dry weight (mg.seedling $\left.{ }^{-1}\right)$; SDW: Shoot dry weight (mg.seedling ${ }^{-1}$ ); ESI: Emergence speed index; FE: Final emergence (\%).

\section{CONCLUSIONS}

The doses of Bacillus subtilis applied, together with physiological conditioning or pelliculation, can be used for treatment of green bean seeds without harming seed lot viability. Phytometric characteristics such as shoot length, root and shoot fresh and dry weight, in addition to the number of secondary roots, are positively influenced by the use of pre-soaked seeds with doses between 16.0 and $20.0 \mathrm{~mL}$ of $\mathrm{cp} . \mathrm{kg}^{-1}$ of seed.

The use of pre-soaking alone brings benefits to the characteristics of electrical conductivity, first germination count and root length, while pelliculation impairs seed performance in the emergence speed index and final emergence tests.

\section{ACKNOWLEDGEMENTS}

To Isla Sementes for their partnership. To the Postgraduate Program in Agronomy at the State University of Londrina and to CAPES for the support and funding of the research. 


\section{REFERENCES}

ARAGÃO, C.A.; DANTAS, B.F.; ALVES, E.; CORRÊA, M.R. Sementes de feijão submetidas a ciclos e períodos de hidratação-secagem. Scientia Agricola, v.59, n.1, p.87-92, 2002. doi.org/10.1590/S0103-90162002000100013

BATISTA, T.B.; BINOTTI, F.F.S.; CARDOSO, E.D.; BARDIVIESSO, E.M.; COSTA, E. Aspectos fisiológicos e qualidade de mudas da pimenteira em resposta ao vigor e condicionamento das sementes. Bragantia, v.74, n.4, p.367-373, 2015. doi.org/10.1590/16784499.0133

BRASIL. Ministério da Agricultura, Pecuária e Desenvolvimento. Regras para análise de sementes. Ministério da Agricultura, Pecuária e Abastecimento. Secretaria de Defesa Agropecuária. Brasília: MAPA/ACS, 2009. 399p. http:// www.agricultura.gov.br/ arq_editor/file/2946_regras_analise_sementes.pdf

BRITO, R.; LOPES, H.M.; FERNANDES, M.C.A.; AGUIAR, L.A.; CEARÁ, P.S. Avaliação da qualidade fisiológica e sanitária de sementes de feijão-vagem (Phaseolus vulgaris L.) produzidas sob manejo orgânico e submetidas ao congelamento. Revista Brasileira de Agroecologia, v.8, n.3, p.131-140, 2013. doi.org/10.33240/rba

CERQUEIRA, W.F.; MORAIS, J.S.; MIRANDA, J.S.; MELLO, I.K.S.; SANTOS, A.F.J. Influência de bactérias do gênero Bacillus sobre o crescimento de feijão comum (Phaseolus vulgaris L.). Enciclopédia Biosfera, v.11, n.20, p.82, 2015. www.conhecer.org.br/ enciclop/2015a/simposio\%20agroecologia/influencia\%20de\%20bacterias.pdf

EL-WAKIL, D.; ESSA, A.M.M. Antagonistic potential of some bacterial strains against Xanthomonas campestris, the cause of bacterial blight in Hordeum vulgare. BioResources, v.15, n.2, p.4205-4216, 2020. https://ojs.cnr.ncsu.edu/index.php/BioRes/article/view/ BioRes_15_2_4205_ElWakil_Antagonistic_Potential_Bacterial_Strains/7667

FANTINEL, V.S.; OLIVEIRA, L.M.; CASA, R.T.; ROCHA, E.C.; SCHNEIDER, P.F.; VICENTE, D. Tratamentos de sementes de goiaba-serrana (Acca sellowiana): efeito na incidência de fungos e na germinação. Revista Brasileira de Biociência, v.13, n.2, p.84-89, 2015. www. ufrgs.br/seerbio/ojs/index.php/rbb/article/view/3178/1276

FERREIRA, D.F. Sisvar: a guide for its bootstrap procedures in multiple comparisons. Ciência e Agrotecnologia, v.38, n.2, p.109-112, 2014. https://doi.org/10.1590/S1413-70542014000200001

JOSHUA, J.; MMBAGA, M. T. Potential biological control agents for soilborne fungal pathogens in Tennessee snap bean farms. HortScience Horts, v.55, n.7, p.988-994, 2020. https://doi.org/10.21273/HORTSCI14081-19

JUNGES, E.; TOEBE, M.; SANTOS, R.F.; FINGER, G.; MUNIZ, M.F.B. Effect of priming and seed-coating when associated with Bacillus subtilis in maize seeds. Revista Ciência Agronômica, v.44, n.3, p.520-526, 2013. doi.org/10.1590/S1806-66902013000300014

KRAUSE, W.; RODRIGUES, R.; LEAL, N.R. Capacidade combinatória para características agronômicas em feijão-de-vagem. Revista Ciência Agronômica, v.43, n.3, p.522-531, 2012. doi.org/10.1590/S1806-66902012000300015

LIMA, L.B.; MARCOS-FILHO, J. Condicionamento fisiológico de sementes de pepino e germinação sob diferentes temperaturas. Revista Brasileira de Sementes, v.32, n.1, p.138-147, 2010. doi.org/10.1590/S0101-31222010000100016

MAGUIRE, J.D. Speed of germination-aid in relation evaluation for seedling emergence vigor. Crop Science, v.2, n.2, p.176-177, 1962.

MARCOS-FILHO, J. Fisiologia de sementes de plantas cultivadas. ABRATES: Londrina, 2015.

NAKAGAWA, J. Testes de vigor baseados no desempenho das plântulas. In: KRZYZANOSKI, F.C.; VIEIRA, R.D.; FRANÇA-NETO, J.B. (ed.). Vigor de sementes: conceitos e testes. ABRATES: Londrina, 1999. p.2.1-2.24.

OLIVEIRA, G.R.F.; SILVA, M.S.; MARCIANO, T.Y.F.; PROENÇA, S.L.; SÁ, M.E. Crescimento inicial do feijoeiro em função do vigor de sementes e inoculação com Bacillus subtilis. Brazilian Journal of Biosystems Engineering, v.10, n.4, p.439-448, 2016. dx.doi. org/10.18011/bioeng2016v10n4p439-448

PETROPOULOS, S.A.; FERNANDES, Â.; PLEXIDA, S.; CHRYSARGYRIS, A.; TZORTZAKIS, N.; BARREIRA, J.C.M.; BARROS, L.; FERREIRA, I.C.F.R. Biostimulants application alleviates water stress effects on yield and chemical composition of greenhouse green bean (Phaseolus vulgaris L.). Agronomy, v.10, n.2, 2020. https://doi.org/10.3390/agronomy10020181 
PRATHIBHA, K.S.; SIDDALINGESHWARA, K.G. Effect of plant growth promoting Bacillus subtilis and Pseudomonas fluorescence as rhizobacteria on seed quality of sorghum. International Journal of Current Microbiology and Applied Sciences, v.2, n.3, p.11-18, 2013. www.ijcmas.com/Archives/vol-2-3/K.S.\%20Prathibha\%20and\%20K.G.Siddalingeshwara.pdf

SANTANNA, C.Q.S.S.; FREITAS, L.B.; OLIVEIRA, T.R.A.; CREVELARI, J.A.; CRUZ, D.P.; GRAVINA, L.M.; ROCHA, R.S.; JAEGGI, M.E.P.C.; PEREIRA, I.M.; OLIVEIRA, M.T.R.; BERBET, P.A.; GRAVINA, G.A. Evaluation of physiological quality of seeds of improved snap bean lines under different storage. Journal of Experimental Agriculture International, v.36, n.4, p.1-10, 2019. doi.org/10.9734/jeai/2019/ v36i430242

SEIF, Y.I.A.; EL-MINIAWY, S.E M.; EL-AZM, N.A.I.A.; HEGAZI, A.Z. Response of snap bean growth and seed yield to seed size, plant density and foliar application with algae extract. Agriculture Science, v.61, n.2, p.187-199, 2016. doi.org/10.1016/j.aoas.2016.09.001

SILVA, K.R.G.; VILLELA, F.A. Pré-hidratação e avaliação do potencial fisiológico de sementes de soja. Revista Brasileira de Sementes, v.33, n.2, p.331-345, 2011. dx.doi.org/10.1590/S0101-31222011000200016

SINGH, A.; GUPTA, R.; PANDEY, R. Rice seed priming with picomolar rutin enhances rhizospheric Bacillus subtilis CIM colonization and plant growth. PLoS One, v.11, n.1, 2016. doi.org/10.1371/journal.pone.0146013

TU, L.; HE, Y.; SHAN, C.; WU, Z. Preparation of microencapsulated Bacillus subtilis sl-13 seed coating agents and their effects on the growth of cotton seedlings. Biomed Research International, , v.2016, p.1-7, 2016. doi.org/10.1155/2016/3251357

VIEIRA, R.D.; KRZYZANOWSKI, F.C. Teste de condutividade elétrica. Vigor de sementes: conceitos e testes. ABRATES: Londrina, 1999. p.1-26. use, distribution, and reproduction in any medium, provided the original work is properly cited. 